\title{
HULL CONTOURS CREATION AND ESTIMATION \\ OF RUNNING CHARACTERISTICS OF NEW GENERATION RIVER-SEA CRUISE PASSENGER SHIPS
}

\author{
СОЗДАНИЕ ОБВОДОВ И ОЦЕНКА ХОДОВЫХ КАЧЕСТВ \\ КРУИЗНЫХ ПАССАЖИРСКИХ СУДОВ СМЕШАННОГО ПЛАВАНИЯ \\ НОВОГО ПОКОЛЕНИЯ
}

\section{СТВОРЕННЯ ОБВОДІВ ТА ОЦІККА ХОДОВИХ ЯКОСТЕЙ КРУЇЗНИХ ПАСАЖИРСЬКИХ СУДЕН ЗМІШАНОГО ПЛАВАННЯ НОВОГО ПОКОЛІННЯ}

\author{
Alexander G. Egorov \\ egorovag@meb.com.ua \\ ORCID 0000-0002-2050-8640
}

\author{
А. Г. Егоров, \\ канд. техн. наук, с. н. с. \\ Marine Engineering Bureau, Odesa \\ Морское Инженерное Бюро, г. Одесса \\ Морське Інженерне Бюро, м. Одеса
}

\begin{abstract}
Purpose - estimation of running characteristics of river-sea passenger ships (PS) of new generation. Methodology. Methods of ship theory and design, analysis and statistical processing are applied. Results. Satisfactory convergence of the results of model and full-scale seaworthy trials on the example of "BBC max" class PS shows effectiveness of used tools. Scientific novelty. For the first time, systematic study of running characteristics of new generation PS of various classes and architectural-structural types has been performed. Practical impact. Main projects of new generation river-sea passenger ships are presented: "PostDnipro max"/"Volgo-Balt" max (dimensions are determined by conditions of Volga-Baltic Way or Dnieper River, passenger capacity is about 500 pax, project PV500); "Dnipro max"/"Volgo-Don" max (dimensions are determined by way conditions of Volga-Don shipping channel or Dnieper river with taking into account optimization of sailing area, passenger capacity is about 250-350 pax, projects PV300, PV300VD, PV250); "Danube Max" (dimensions are determined by way conditions of Danube River and interbasin Danube-Main-Rhine junction, passenger capacity is about 200 pax, project PV200D); "BBC max" (dimensions are determined by way conditions of Belomor-Baltic Canal, passenger capacity is about 150-200 pax, projects PV09, PV11, PV150, PV200BB). Features of their contours are highlighted in comparison with classical Soviet period ships. For our operational conditions traditional single hull type of passenger ship is most suitable. Ships differ from classic PS projects built in Soviet time, with the L/B ratio - for the most part ("Dnipro max"/"Volgo-Don" max and "PostDnipro max"/"Volgo-Balt max" classes) are longer, by contours of fore and aft ends - optimized with computational fluid dynamics (CFD) methods, and also designed with taking into account installation of bow thrusters and rudder-propellers respectively. Results of research of running characteristics of new generation PS, which were executed by CPD methods are shown. Information of 2019 full-scale seaworthy tests of new generation PV09 concept PS of "BBC max" class is also presented and analyzed.
\end{abstract}

Key words: river-sea cruises; ship design; propulsion complex; model and full-scale trials; ecology; efficiency.

Анотація. Мета - оцінка ходових якостей пасажирських суден змішаного плавання (ПС) нового покоління. Методика. Застосовано методи теорії і проєктування корабля, аналізу і статистики. Результати. Задовільна збіжність результатів модельних і натурних морехідних випробувань на прикладі ПС «ББК макс» класу показує ефективність застосовуваних інструментів. Наукова новизна. Вперше виконано системні дослідження ходових якостей ПС нового покоління різних класів і архітектурно-конструктивних типів. Практичне значення. Наведено основні проєкти круїзних пасажирських суден змішаного плавання нового покоління: «ПостДніпро макс»/«Волго-Балт макс» (розміри визначаються умовами Волго-Балтійського шляху або річки Дніпро, пасажиромісткість приблизно 500 осіб, проєкт PV500); «Дніпро макс»/«Волго-Дон макс» (розміри визначаються шляховими умовами Волго-Донського судноплавного каналу або річки Дніпро з урахуванням оптимізації за районом плавання, пасажиромісткість приблизно 250-350 осіб, проєкти PV300, PV300VD, PV250); «Дунай макс» (розміри визначаються шляховими умовами річки Дунай і міжбасейнового з'єднання ДунайМайн-Рейн, пасажиромісткість приблизно 200 осіб, проєкт PV200D); «ББК макс» (розміри визначаються 
шляховими умовами Біломорсько-Балтійського каналу, пасажиромісткість приблизно 150-200 осіб, проєкти PV09, PV11, PV150, PV200BВ). Підкреслено особливості їх обводів порівняно з класичними суднами радянського періоду. Для наших умов експлуатації найбільш відповідним є традиційний монокорпусний тип пасажирського судна. Судна відрізняються від класичних проєктів ПС, побудованих за радянських часів, співвідношенням $L / B$ - здебільшого («Дніпро макс»/«Волго-Дон макс» і «ПостДніпро макс»/«Волго-Балт макс» класи) довші, обводами носових і кормових країв - оптимізовані за допомогою методів обчислювальної гідродинаміки (ОГд), а також спроєктовані з урахуванням установлення підрулюючих пристроїв і гвинторульових колонок відповідно. Показані результати досліджень ходових якостей ПС нового покоління, виконаних за допомогою методів ОГД. Наведено і проаналізовано також дані натурних морехідних випробувань 2019 року ПС нового покоління «ББК макс» класу концепту PV09.

Ключові слова: ріка-море круїзи; проєктування судна; пропульсивний комплекс; модельні та натурні випробування; екологія; ефективність.

Аннотация. Цель - оценка ходовых качеств пассажирских судов смешанного плавания (ПС) нового поколения. Методика. Применены методы теории и проектирования корабля, анализа и статистики. Результаты. Удовлетворительная сходимость результатов модельных и натурных мореходных испытаний на примере ПС «ББК макс» класса показывает эффективность применяемых инструментов. Научная новизна. Впервые выполнены системные исследования ходовых качеств ПС нового поколения различных классов и архитектурноконструктивных типов. Практическое значение. Приведены основные проекты круизных пассажирских судов смешанного плавания нового поколения. Подчёркнуты особенности их обводов по сравнению с классическими судами советского периода. Показаны результаты исследований ходовых качеств ПС нового поколения, выполненных с помощью методов ВГД. Приведены и проанализированы также данные натурных мореходных испытаний 2019 года ПС нового поколения «ББК макс» класса концепта PV09.

Ключевые слова: река-море круизы; проектирование судна; пропульсивный комплекс; модельные и натурные испытания; экология; эффективность.

\section{ПОСТАНОВКА ЗАДАЧИ}

Новое поколение круизных пассажирских судов смешанного и речного плавания значительно отличается от классических речных и модернизированных до смешанного класса круизных пассажирских судов как по своему техническому оснащению, так и концептуально - другие подходы к определению главных

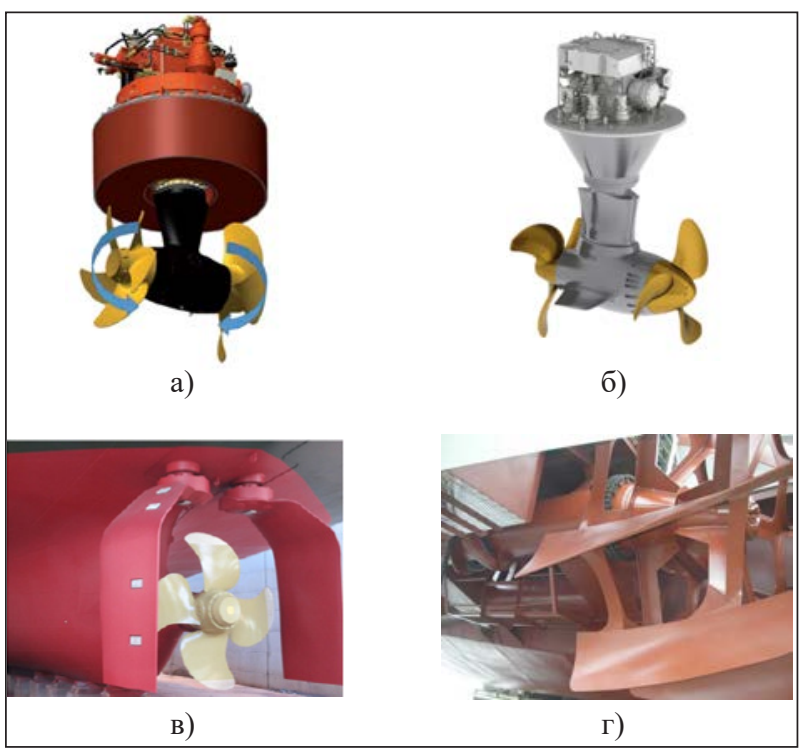

Рис 1. Современные пропульсивные комплексы, которые могут быть использованы на ПС нового поколения: а) ВРК VETH VZ-900A [8], б) ВPK STP 310 [9], в) "Gate rudder" система [10], г) колёсный ДРК Е.В. Фальмонова размерений, обводов, формированию пассажирских и общественных помещений [1-6].

Применение принципа максимального использования габаритов внутренних водных путей, для которых проектируется судно, а также внедрение новых пропульсивных комплексов (винто-рулевые колонки - ВРК и азимутальные [7-9], винт с поворотным симметричным двухсторонним рулем ("gate rudder" система) [10], колёсные движительно-рулевые - ДРК [11], см. рисунок 1) по аналогии с грузовыми судами [12] привели к необходимости создания новых эффективных обводов. При этом сами обводы создаются и оптимизируются в программных комплексах, которых просто не существовало на момент проектирования существующих ныне ПС.

\section{АНАЛИЗ ПОСЛЕДНИХ ИССЛЕДОВАНИЙ И ПУБЛИКАЦИЙ И ВЫДЕЛЕНИЕ НЕ РЕШЕННЫХ РАНЕЕ ЧАСТЕЙ ОБЩЕЙ ПРОБЛЕМЫ}

В литературе отсутствуют системные исследования ходовых качеств круизных пассажирских судов смешанного плавания нового поколения. Приведены данные по исследованиям определённых судов $[6 ; 13-16]$.

Обводы и ходовые качества судна непосредственно влияют на экономику и эффективность судна в эксплуатации, поэтому крайне важным является получить возможность качественной оценки ходовых качеств ПС нового поколения на этапе проектирования. 


\section{СУДНОБУДУВАННЯ № 1 - 2020}

Целью исследования является оценка ходовых качеств ПС нового поколения, разработанных Морским Инженерным Бюро.

\section{МЕТОДЫ, ОБЪЕКТ И ПРЕДМЕТ ИССЛЕДОВАНИЯ}

Применялись методы теории и проектирования корабля, анализа и статистики. Объект - круизные ПС смешанного и речного плавания. Предмет - обводы и ходовые качества круизных ПС.

\section{ОСНОВНОЙ МАТЕРИАЛ}

Разработанная Бюро линейка ПС нового поколения включает в себя все основные классы: «ПостДнепро макс»/«Волго-Балт макс» (размеры определяются условиями Волго-Балтийского пути или реки Днепр, пассажировместимость около 500 человек, проект PV500); «Днепро макс»/«Волго-Дон макс» (размеры определяются путевыми условиями Волго-Донского судоходного канала или реки Днепр с учётом оптимизации района плавания, пассажировместимость около 250-350 человек, проекты PV300, PV300VD, PV250); «Дунай макс» (размеры определяются путевыми условиями реки Дунай и межбассейнового соединения Дунай-Майн-Рейн, пассажировместимость около 200 человек, проект PV200D); «ББК макс» (размеры определяются путевыми условиями Беломорско-Балтийского канала, пассажировместимость около 150-200 человек, проекты PV09, PV11, PV150, PV200BB).

Как было отмечено в [3], для наших условий эксплуатации наиболее подходящим является традиционный монокорпусный тип пассажирского судна.

Остановимся более детально на некоторых проектах:

- ПC проекта PV300VD «Днепро макс»/ «Волго-Дон макс» класса;

- ПС проекта PV250 «Днепро макс»/«Волго-Дон макс» класса (пассажирский барже-буксирный состав);

- ПС проекта PV150 «ББК макс» класса (классические обводы и пропульсия);

- ПС проекта PV09 «ББК макс» класса (современные обводы и ВРК).

ПС проекта PV300VD - стальное самоходное трёхвинтовое (в первоначальном варианте на этапе строительства была выполнена замена на 3 ВРК) судно с наклонным форштевнем и транцевой кормовой оконечностью, с избыточным надводным бортом, с удлинённой надстройкой бака, надстройкой юта, со средним расположением четырёхъярусной надстройки, с носовым расположением рулевой рубки, с машинным отделением в кормовой части.

ПС проекта PV250 (пассажирский барже-буксирный состав) - стальное составное судно с избыточным надводным бортом, с надстройкой бака на основной секции, надстройкой юта на энергетической сек- ции, со средним расположением трёхъярусной надстройки основной секции, с носовым расположением подъёмной (для обеспечения обзора) рулевой рубки на энергетической секции, с машинным отделением в кормовой части энергетической секции с 2 полноповоротными ВРК с гребными винтами в насадках. Корпус пассажирской секции имеет носовую оконечность с наклонным форштевнем и транцевую кормовую оконечность с упрощёнными обводами. Корпус энергетической секции имеет упрощённые обводы в носовой части, рассчитанные на совместное обтекание в составе с баржей-приставкой, и транцевую кормовую оконечность с неглубокими полутоннелями и скегом

ПС проекта PV150 - стальное самоходное трёхвинтовое судно с наклонным форштевнем и транцевой кормовой оконечностью, с избыточным надводным бортом, с надстройкой бака и юта со средним расположением трёхъярусной надстройки с носовым расположением рулевой рубки, с машинным отделением в кормовой части.

ПС проекта PV09 - стальное самоходное судно с избыточным надводным бортом, с вертикальным форштевнем и транцевой кормовой оконечностью, со средним расположением двухъярусной надстройки, с носовым расположением рулевой рубки, с машинным отделением в кормовой части, с дизель-электрической энергетической установкой, с двумя полноповоротными ВРК и носовым подруливающим устройством.

Модельные испытания ПС нового поколения. Обводы ПС нового поколения создавались в программных комплексах Rhinoceros и CAESES (Friendship Systems) и оптимизировались с помощью методов ВГД в среде FlowVision.

Моделирование буксировочных испытаний исследуемых ПС во FlowVision выполнено путём решения уравнений Рейнольдса конечно-объёмным методом в расчётной области, внутрь которой помещена 3D модель корпуса судна. Расчёты выполнены в масштабе натуры с намерением избежать влияния масштабных эффектов и процедур пересчёта с модели на натуру, с учётом условий эксплуатации реальных судов [13-16].

Боковые виды ПС нового поколения приведены в таблице 1. Теоретические чертежи ПС нового поколения приведены в таблице 2.

Геометрические характеристики подводной части корпусов ПС нового поколения представлены в таблице 3.

Обводы моделей ПС нового поколения приведены на рисунках 2 и 3.

Результаты расчёта буксировочного сопротивления и мощности ПС нового поколения представлены в таблице 4, графически - на рисунке 4.

Визуализация расчётов для скорости 14 узлов (PV300, PV250, PV150) и 12,5 (PV09) представлена на рисунке 5. 
Таблица 1. Боковые виды ПС нового поколения

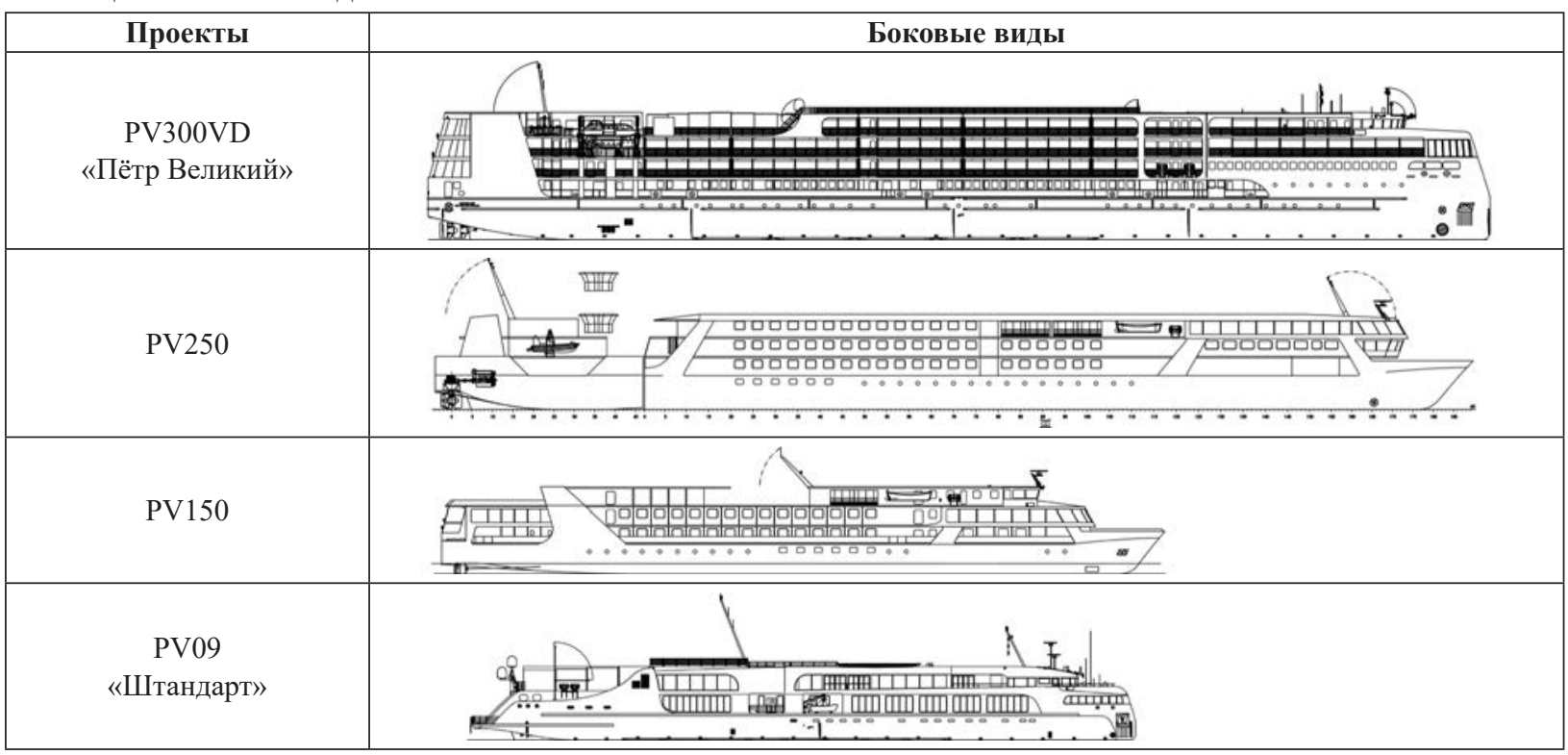

Таблица 2. Теоретические чертежи ПС нового поколения

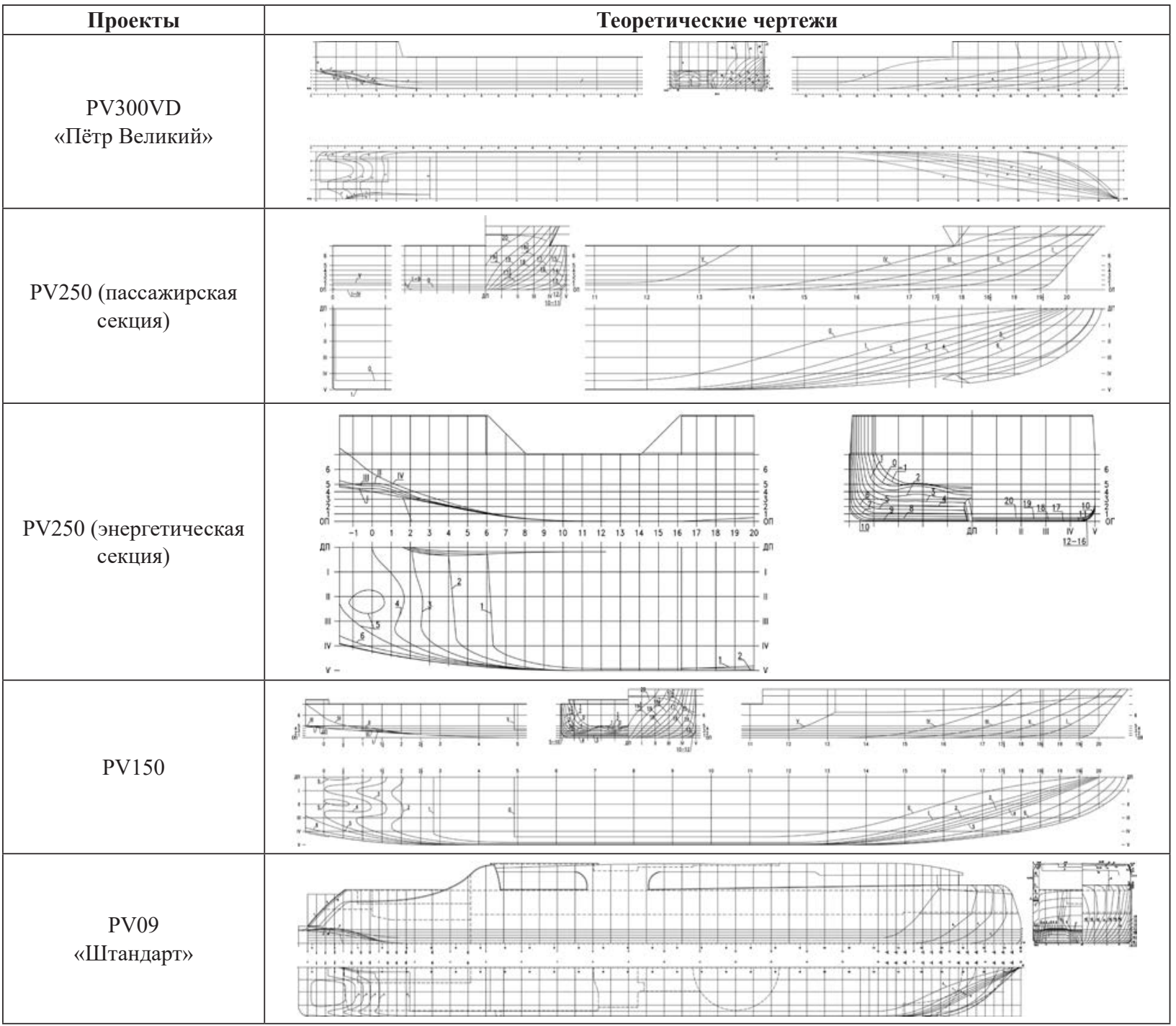




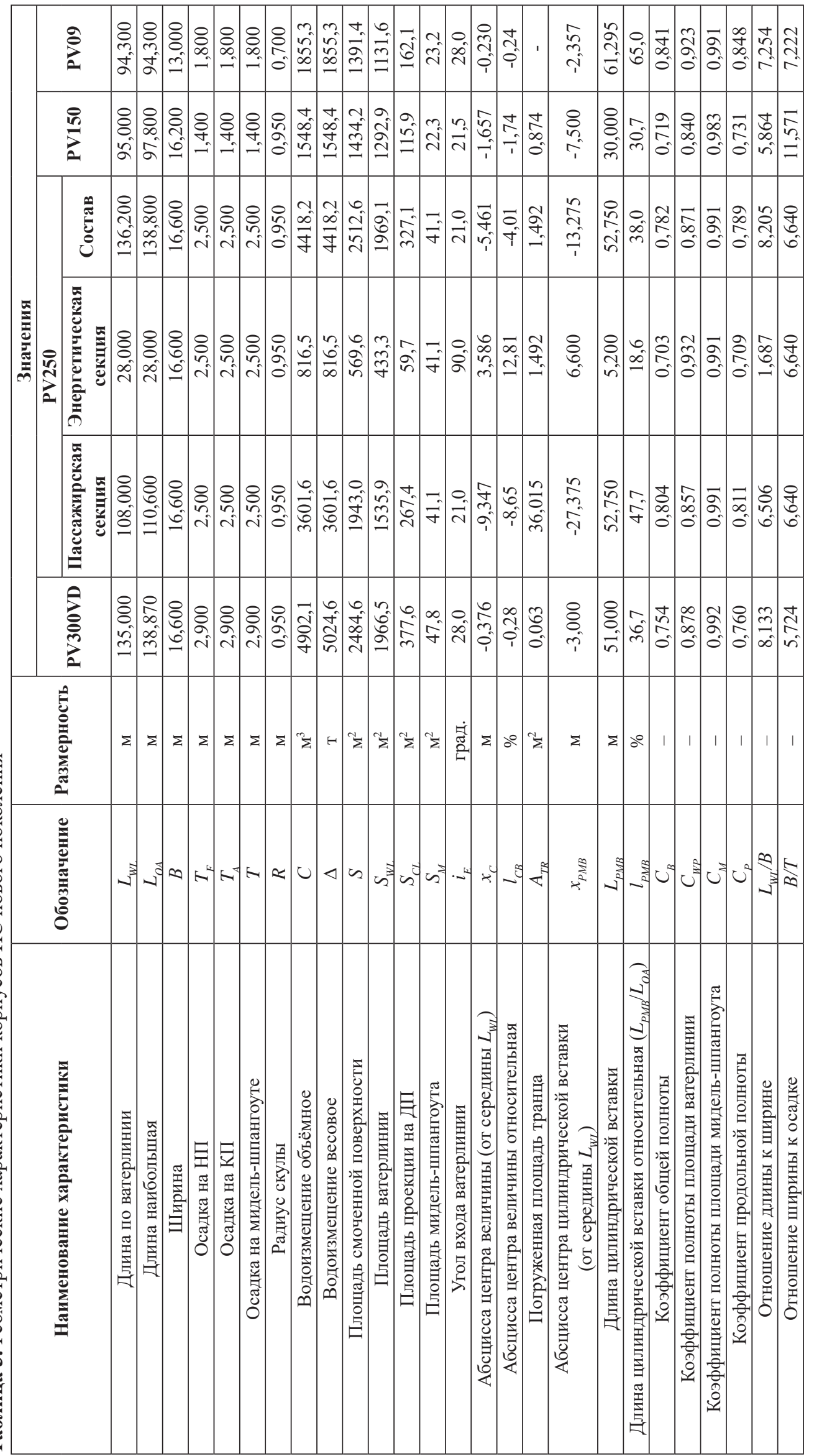




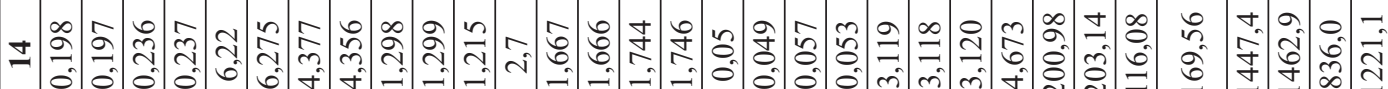

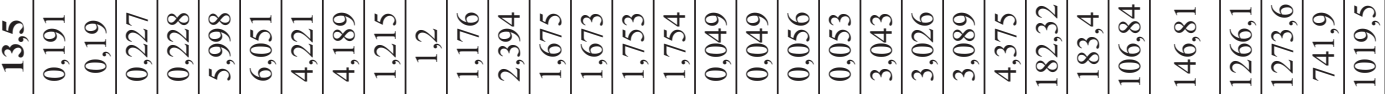

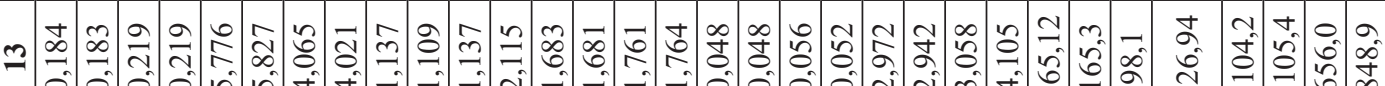

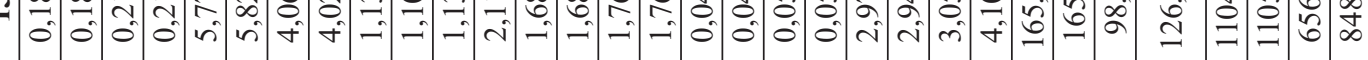

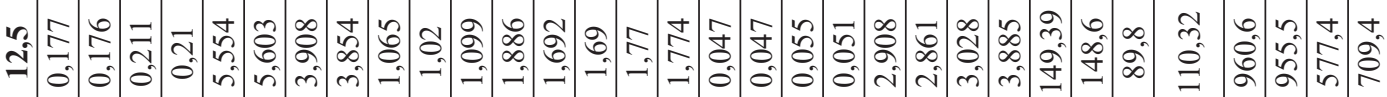

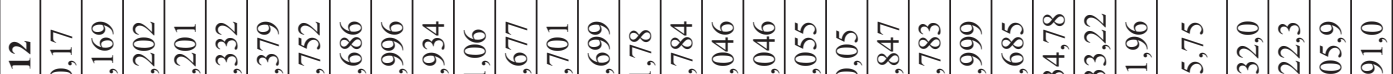

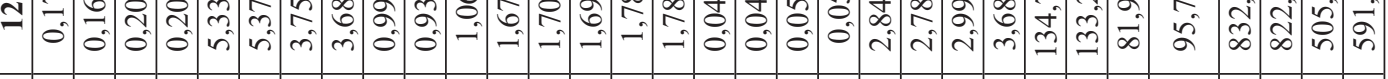
$\because$ 象 $=0$ :

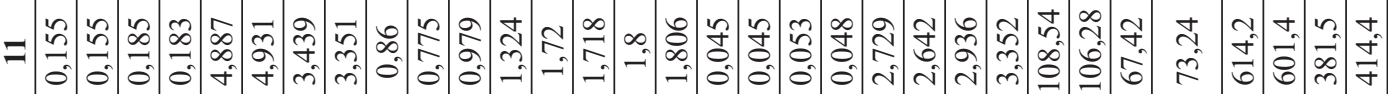

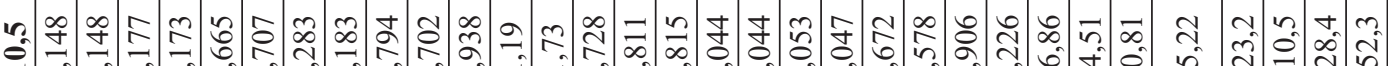

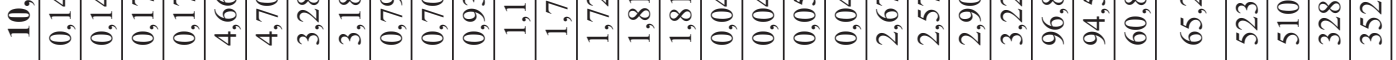

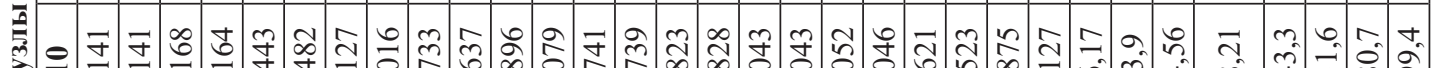

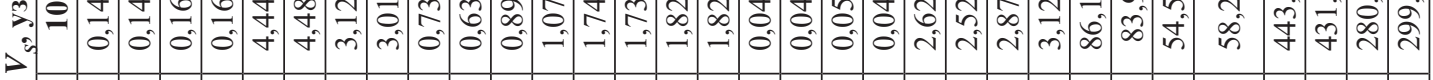

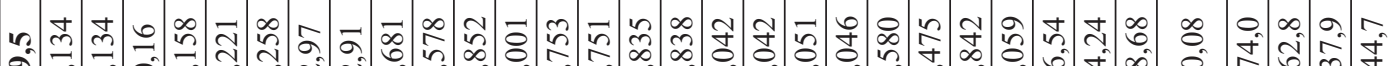
م.

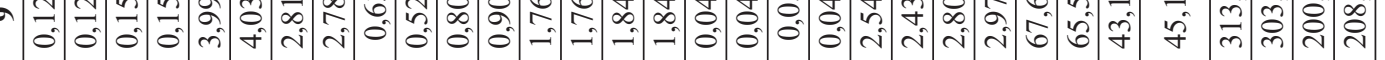

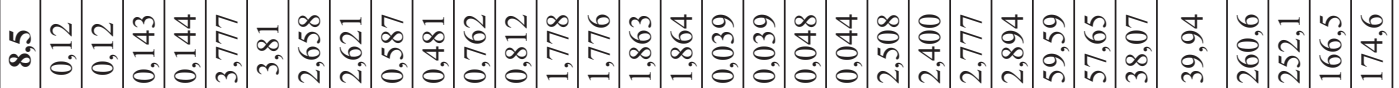

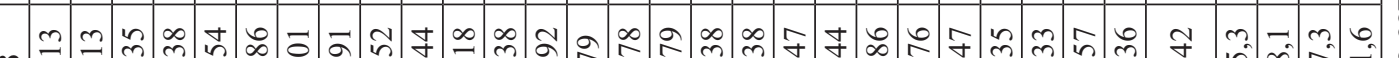

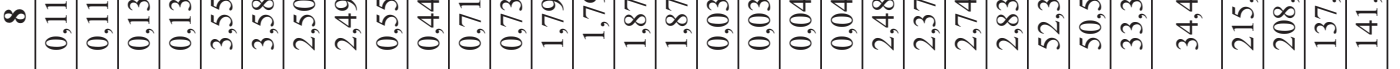
n: i.

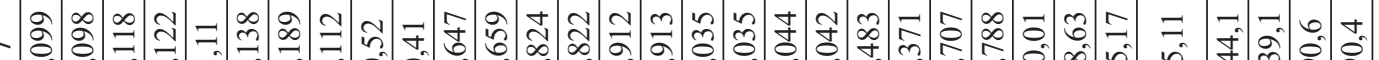
$\therefore$ : 0 o

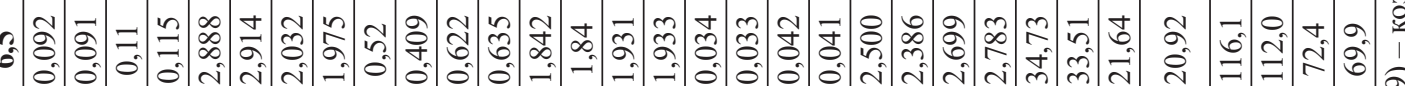

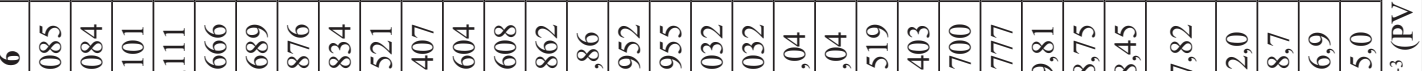

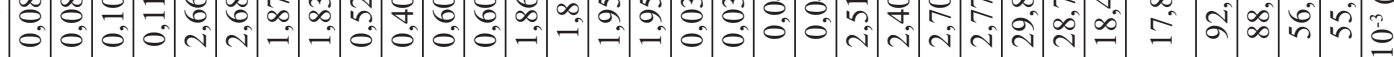

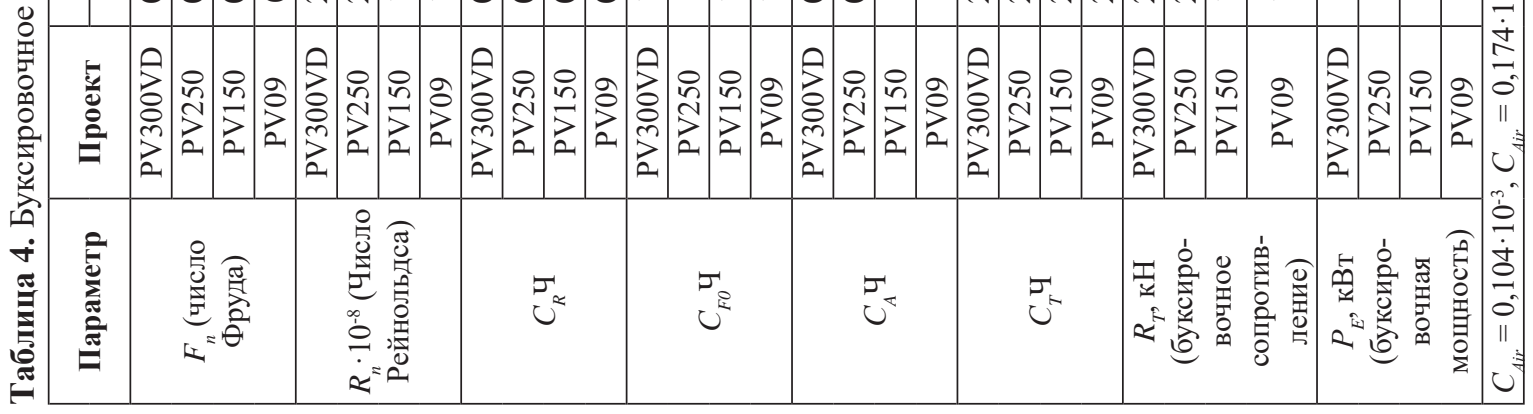




\section{СУДНОБУДУВАННЯ № 1 - 2020}

Подбор оптимальных характеристик винтов и расчёт ходовых качеств судов с классическим пропульсивным комплексом был выполнен с использованием результатов систематических модельных испытаний серии М 4-65, с ВРК - с использовани-

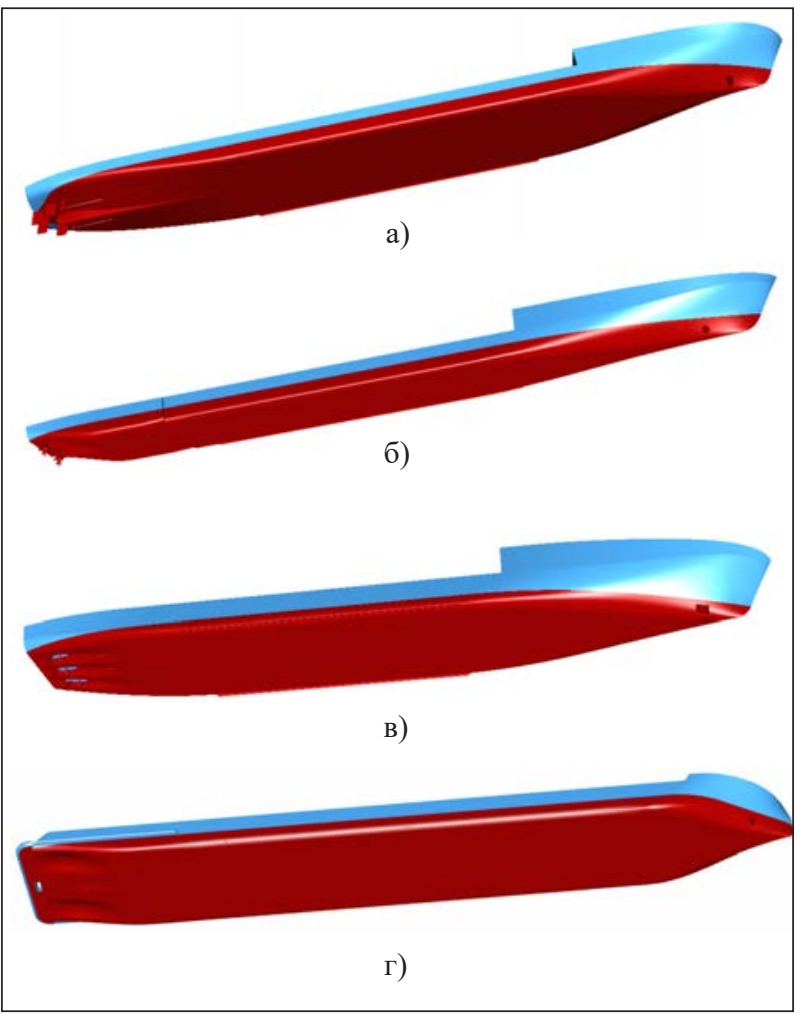

Рис. 2. Обводы моделей ПС нового поколения. Общий вид: а) PV300VD, б) PV250, в) PV150, г) PV09 ем гидродинамических характеристик серийных винтов Ка 4-70 в направляющих насадках 19А (см. таблицу 5).

Зависимости между скоростью хода ПС нового поколения, нагрузкой ГД по мощности и числом

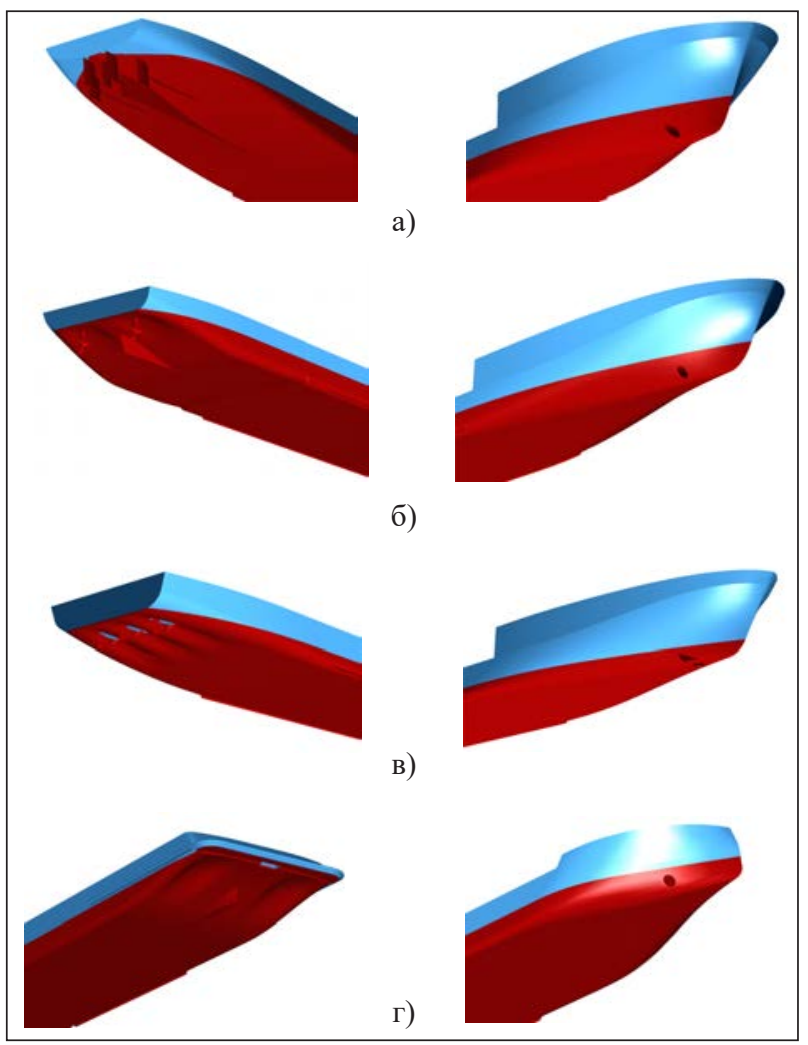

Рис. 3. Обводы моделей ПС нового поколения. Кормовая и носовая оконечности: a) PV300VD, б) PV250, в) PV150, г) PV09

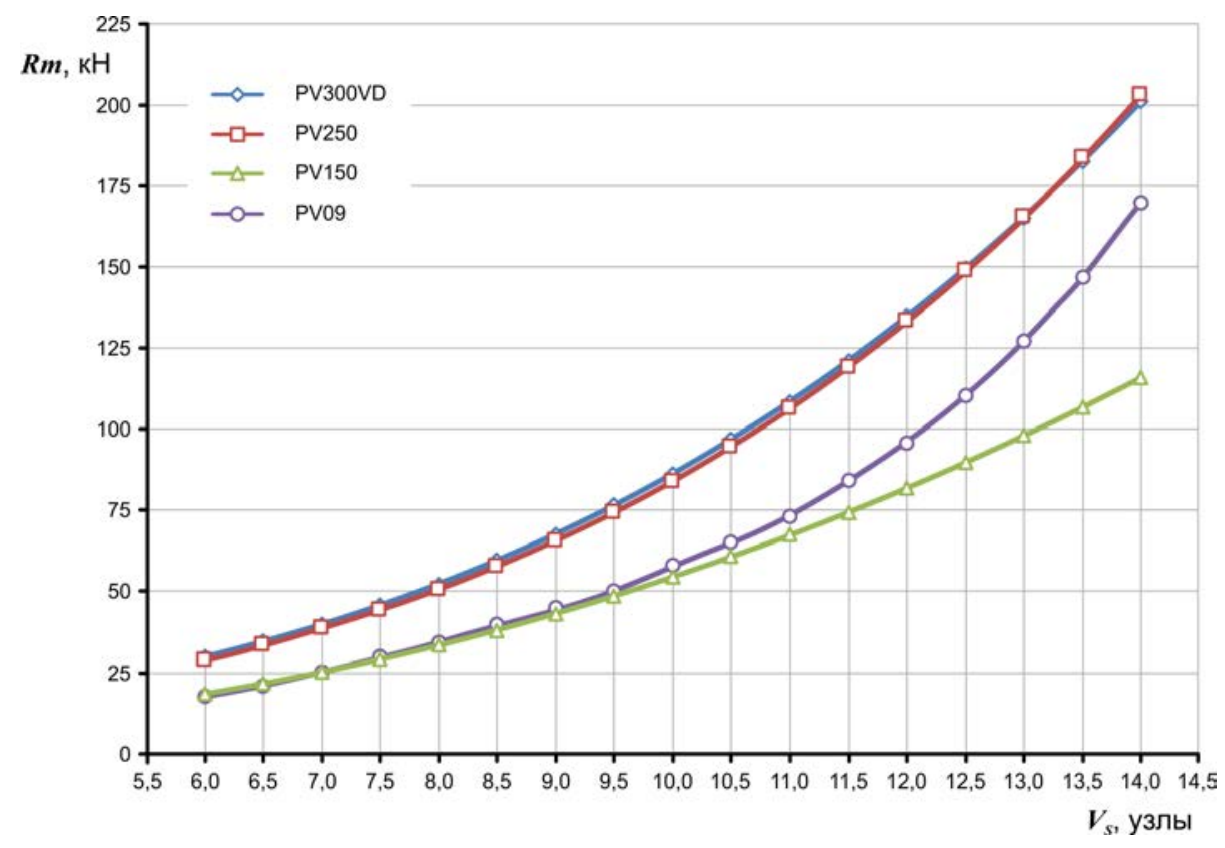

Рис. 4. Буксировочное сопротивление ПС нового поколения 
оборотов гребных валов представлены в таблице 6 (графически - см. рисунок 6).

Для проекта PV09 расчёт ходовых качеств судна был выполнен с использованием дан-

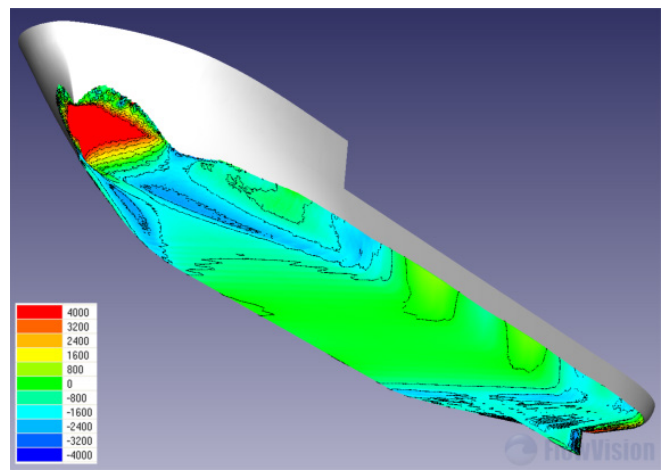

ных производителя ВРК Rolls-Royce US $155 \mathrm{P} 14$ CRP [17] (2 x 1100 кВт, см. таблицу 7). Согласно результатам расчётов, скорость хода на тихой глубокой воде с $\quad$ BPK US 155P14 CRP

a)
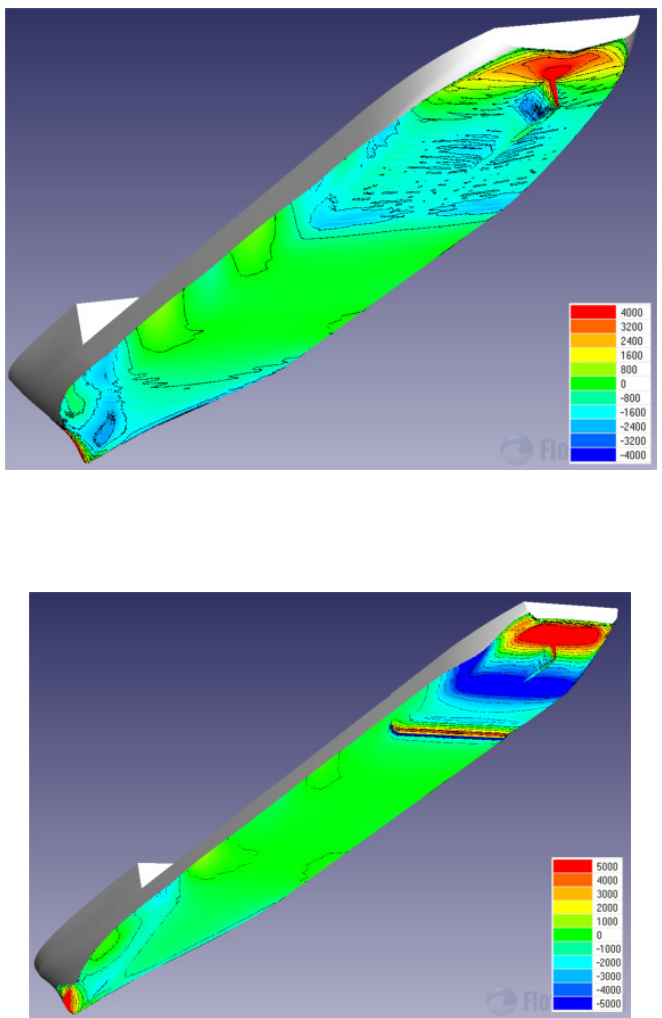

б)

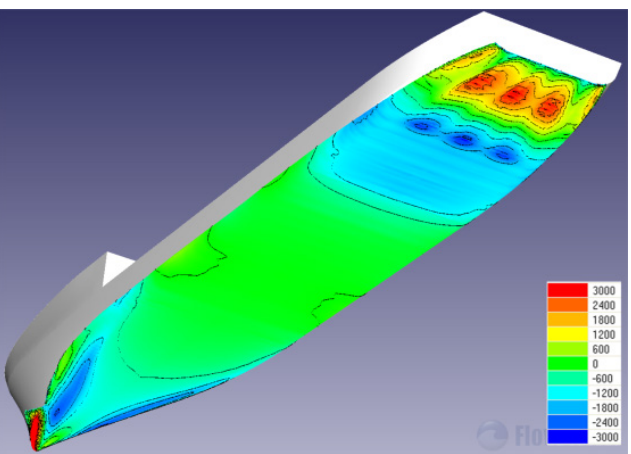

в)

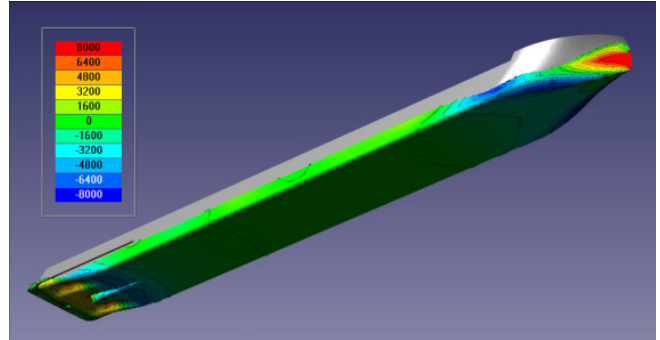

г)

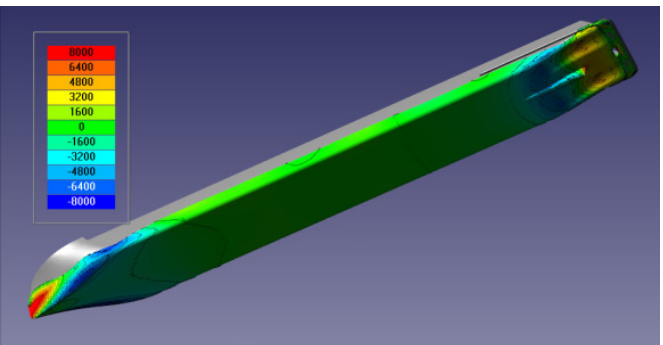

Рис. 5. Визуализация расчётов для максимальных скоростей ПС нового поколения. Распределение давления воды: а) PV300VD, б) PV250, в) PV150, г) PV09 


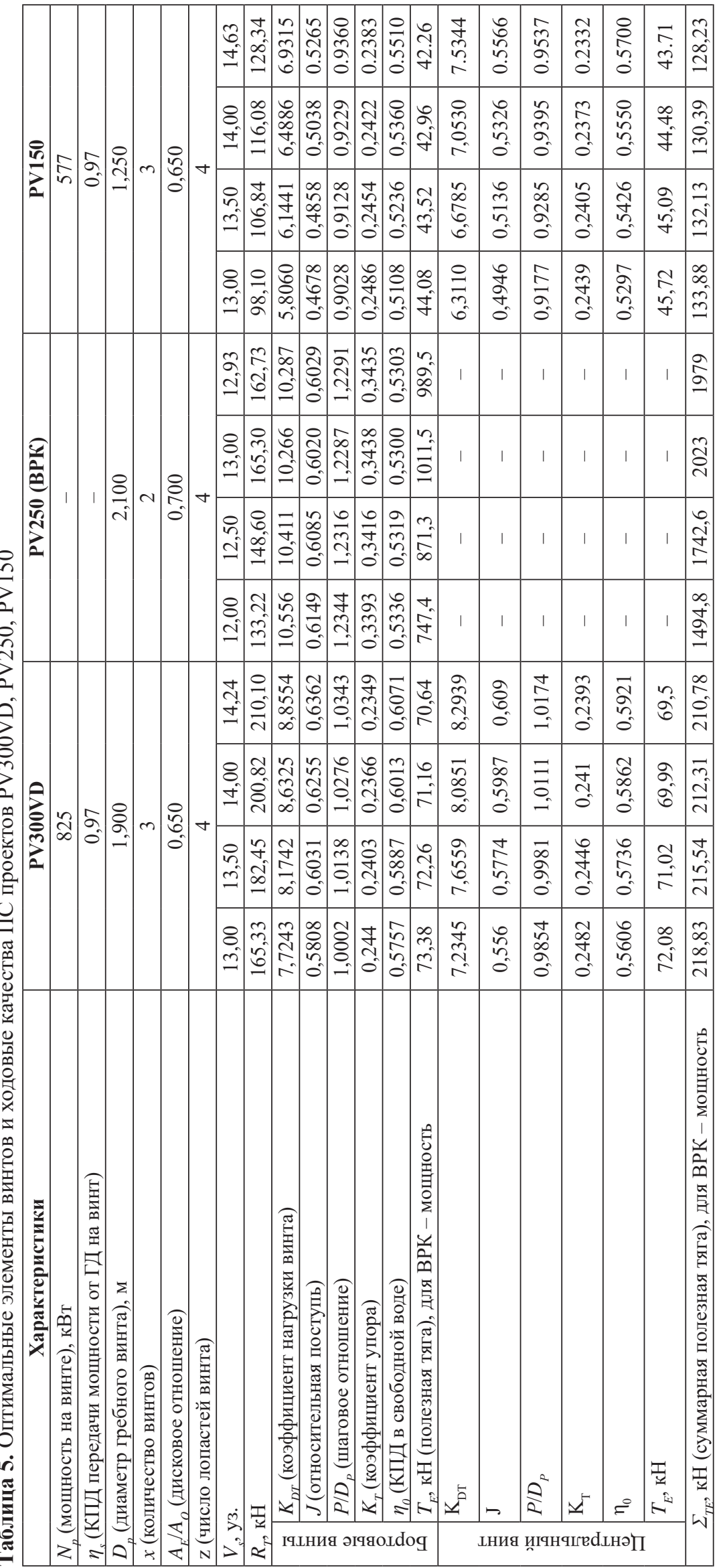




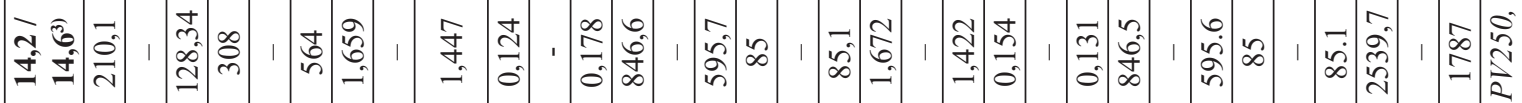

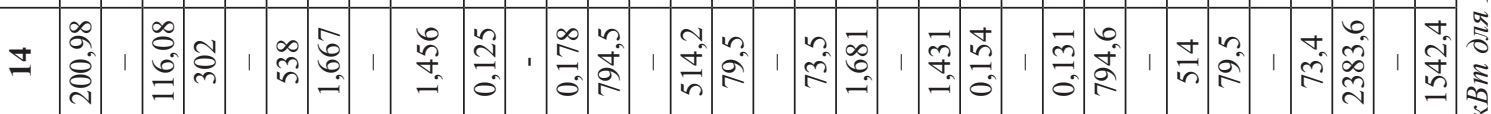

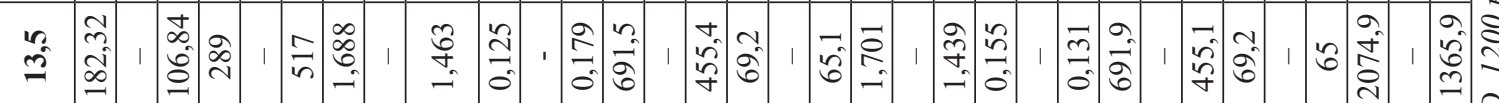

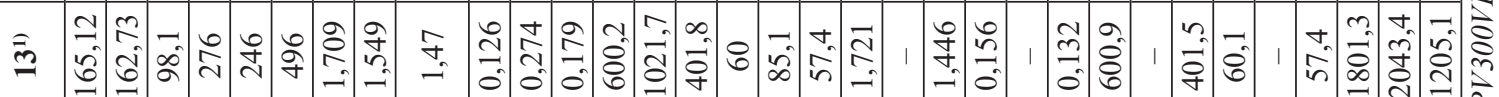

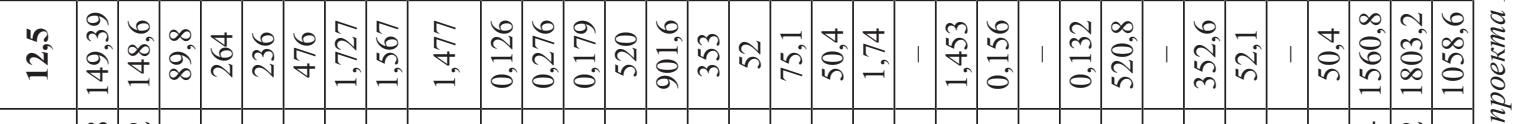

$\stackrel{\circ}{2}$

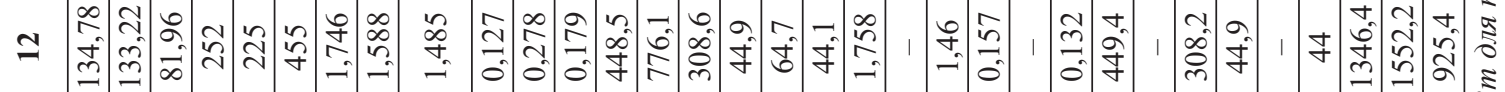

n.

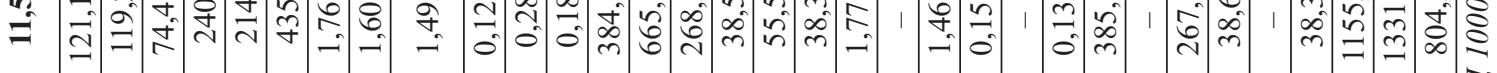

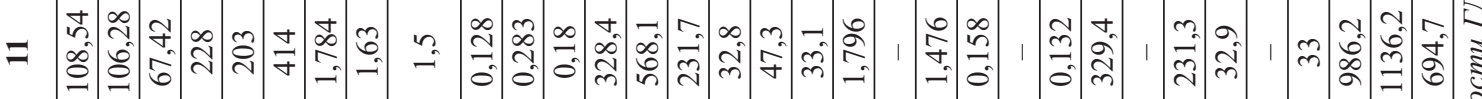

잉

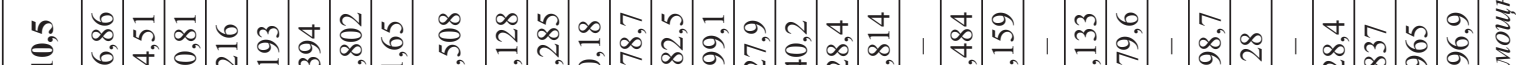

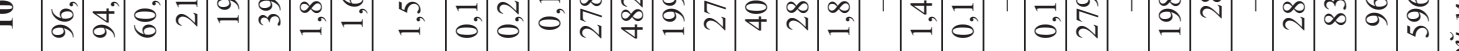

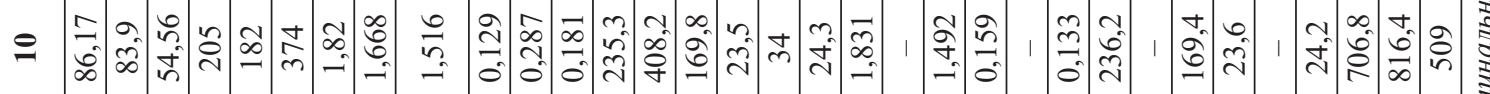

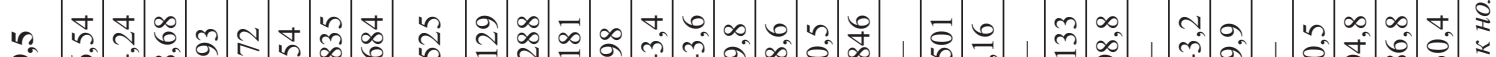

م.

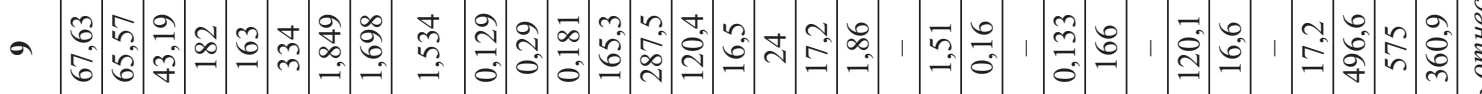

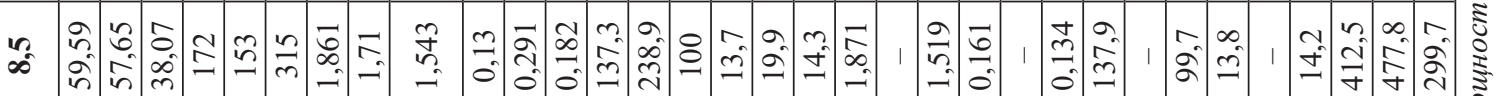

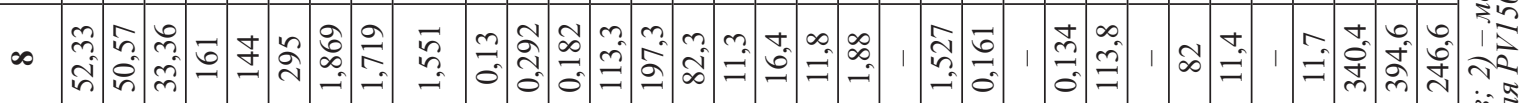

केष्ठ

n क

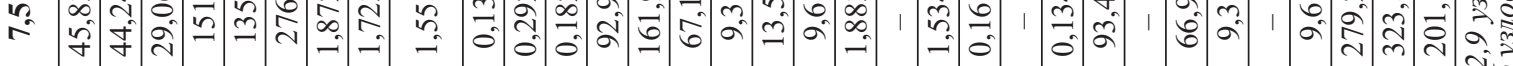

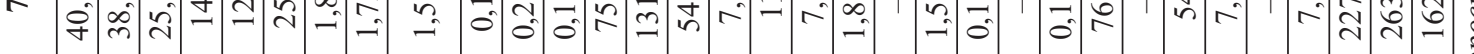

n.

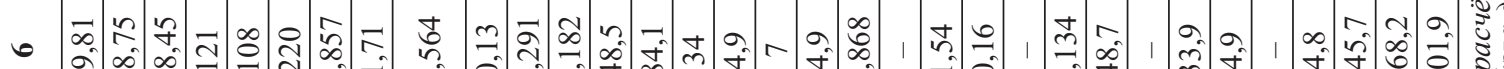

ปो

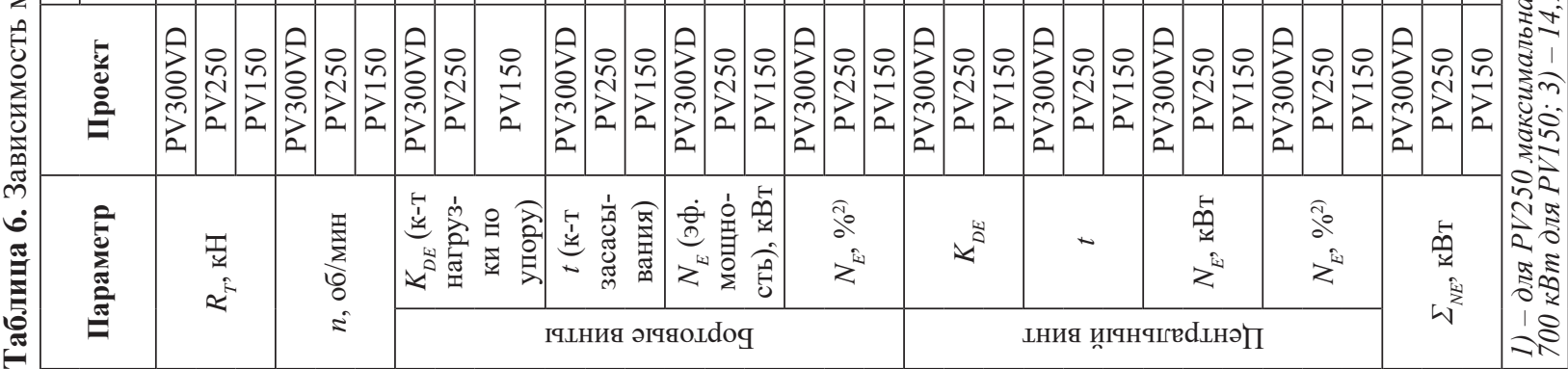




\section{СУДНОБУДУВАННЯ № 1 - 2020}

составляет 13,7 узла при 100\% мощности главных двигателей (2 x 1100 кВт).

Расчётная скорость хода на тихой и глубокой воде ПС проекта PV300VD - 14,24 узла при 85\% (3 x 825 кВт) нагрузке главных двигателей, ПС проекта PV250 - 12,93 узла при 85\% (2 х 989 кВт), ПС проекта PV150 - 14,63 узла при 85\% (3 х 577 кВт).

Натурные испытания ПС нового поколения. ПC проекта PV300VD «Пётр Великий» спущен на воду в мае 2019 года, находится на достройке (см. рисунок 7), ходовые испытания ещё не были проведены. ПС проекта PV300 «Мустай Карим», обводы которого близки к обводам ПС проекта PV300VD (разница в кормовой оконечности и пропульсивном комплексе - установлены 2 ВРК мощностью 1200 кВт каждая вместо таких же трёх) спущен на воду в сентябре 2019 года (см. рисунок 8), сдача планируется весной/ летом 2020 года, предварительные ходовые испытания подтвердили (с запасом) контрактную скорость судна.
ПС проект PV09 «Штандарт» был сдан в эксплуатацию в 2017 году. В процессе строительства было принято решение о замене ВРК на SCHOTTEL STP 550 (2 х 1000 кВT), соответственно уменьшилась и расчётная скорость.

Ходовые испытания подтвердили мореходные качества ПС «Штандарт» проекта PV09. Судно на мерной миле развило максимальную скорость 23,8 км/ч. В 2019 году были проведены расширенные мореходные испытания «Штандарта» [18; 19] с целью подтверждения выполнения условий смешанного класса М-ПР 2,5 РРР (см. рисунок 9).

Испытания проводились при значении оборотов ГДГ 1500 об/мин, при пяти значениях курсового угла волнения (КУВ): $0^{\circ}, 45^{\circ}, 90^{\circ}, 135^{\circ}$ и $180^{\circ}\left(0^{\circ}\right.$ соответствует движению против волны). При маневрировании судно поворачивалось к волне как правым, так и левым бортом. При проведении испытаний на каждом этапе судно двигалось прямым курсом

Таблица 7. Расчёт ходовых качеств ПС проекта PV09 с BPK Rolls-Royce US 155P14 CRP

\begin{tabular}{|c|c|c|c|c|c|c|c|c|c|c|}
\hline$V_{s}$, узлы & $t$ & $J$ & $K_{D T}$ & $\eta_{0}$ & $\boldsymbol{K}_{T}$ & $T_{E}, \mathbf{\kappa H}$ & $n$, об/мин & $N_{E}$, кBТ & $N_{E}, \%$ & $\Sigma_{N E}, \mathbf{K B T}$ \\
\hline 9,7 & 0,210 & 0,6992 & 7,338 & 0,5790 & 0,3818 & 34,46 & 678 & 260 & 23,6 & 520 \\
\hline 10,3 & 0,210 & 0,6927 & 7,401 & 0,5761 & 0,3867 & 39,61 & 723 & 317 & 28,8 & 634 \\
\hline 10,8 & 0,210 & 0,6850 & 7,476 & 0,5725 & 0,3925 & 45,56 & 769 & 386 & 35,1 & 772 \\
\hline 11,3 & 0,210 & 0,6756 & 7,570 & 0,5677 & 0,3997 & 52,59 & 819 & 471 & 42,8 & 942 \\
\hline 11,9 & 0,210 & 0,6655 & 7,669 & 0,5625 & 0,4073 & 60,60 & 871 & 574 & 52,2 & 1148 \\
\hline 12,4 & 0,210 & 0,6547 & 7,777 & 0,5566 & 0,4154 & 69,82 & 926 & 699 & 63,5 & 1398 \\
\hline 13,0 & 0,210 & 0,6433 & 7,889 & 0,5502 & 0,4239 & 80,34 & 983 & 849 & 77,2 & 1698 \\
\hline 13,5 & 0,210 & 0,6303 & 8,018 & 0,5426 & 0,4337 & 92,91 & 1045 & 1037 & 94,3 & 2074 \\
\hline 14,0 & 0,210 & 0,6169 & 8,150 & 0,5345 & 0,4437 & 107,31 & 1110 & 1265 & 115,0 & 2530 \\
\hline
\end{tabular}

Источник: [17]

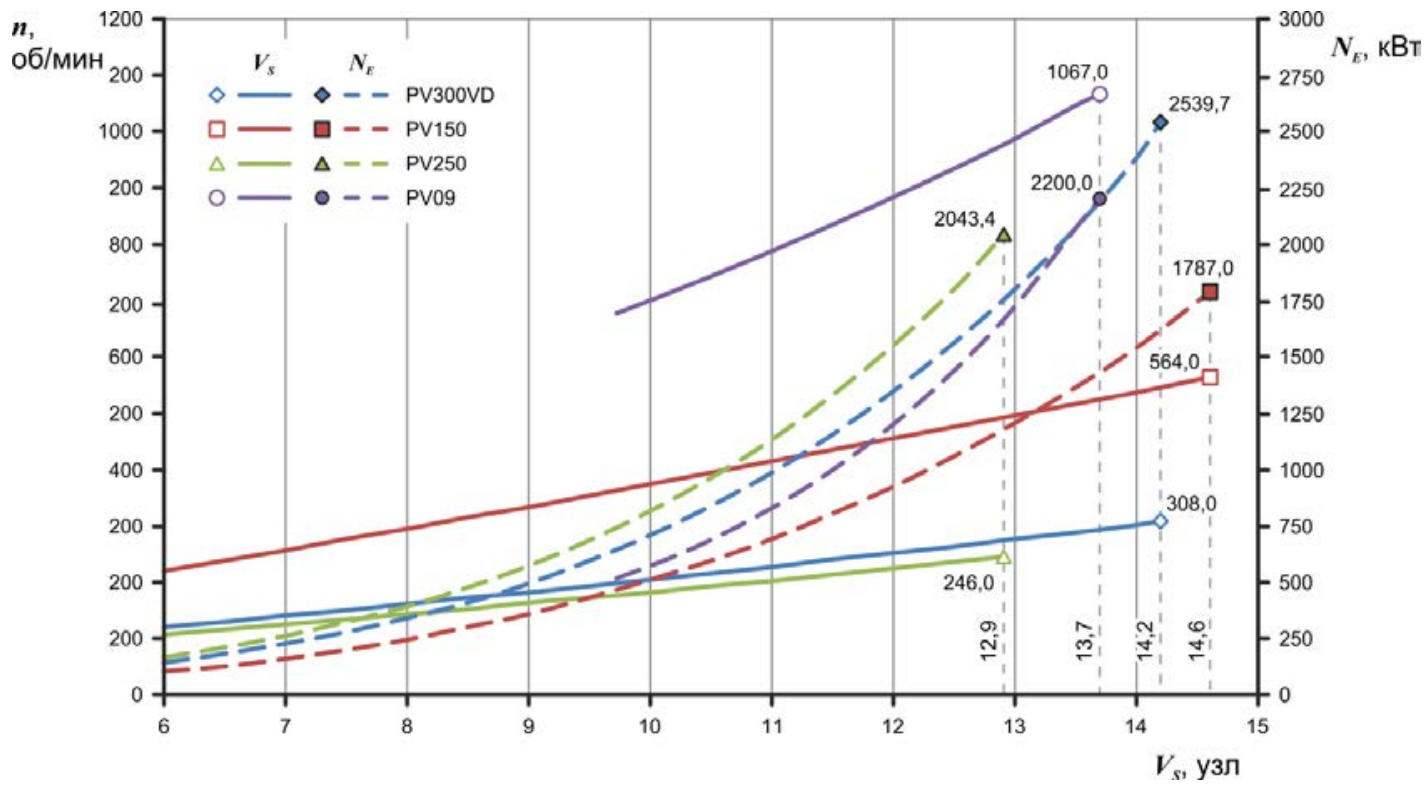

Рис. 6. Расчёт ходовых качеств ПС нового поколения 
с постоянными оборотами ГД; время удержания судна на каждом курсе составляло 9-12 мин.

На основании проведённых испытаний и наблюдений установлено, что судно показало годные мореходные качества, а именно: уверенную управ- ляемость на переднем ходу, умеренную качку, умеренную забрызгиваемость, заливаемость кринолина (в корме) на КУВ 90-180 (что вполне ожидалось, учитывая выбранный архитектурно-конструктивный тип судна), потерю скорости переднего хода на
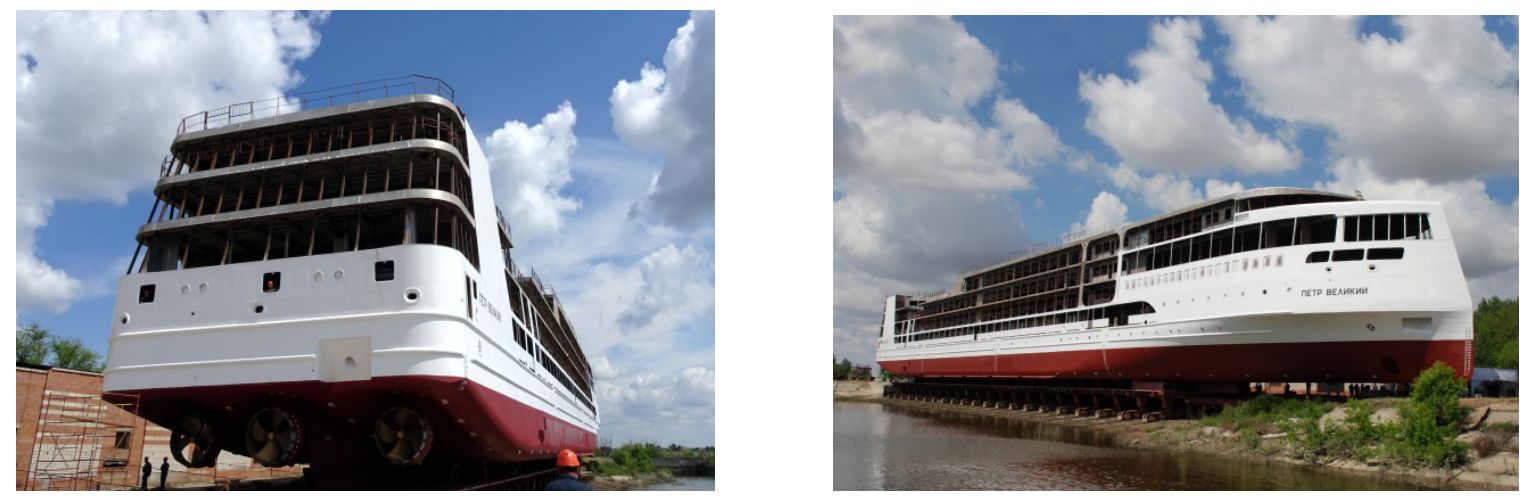

Рис. 7. Носовая и кормовая оконечности ПС проекта PV300VD «Пётр Великий»
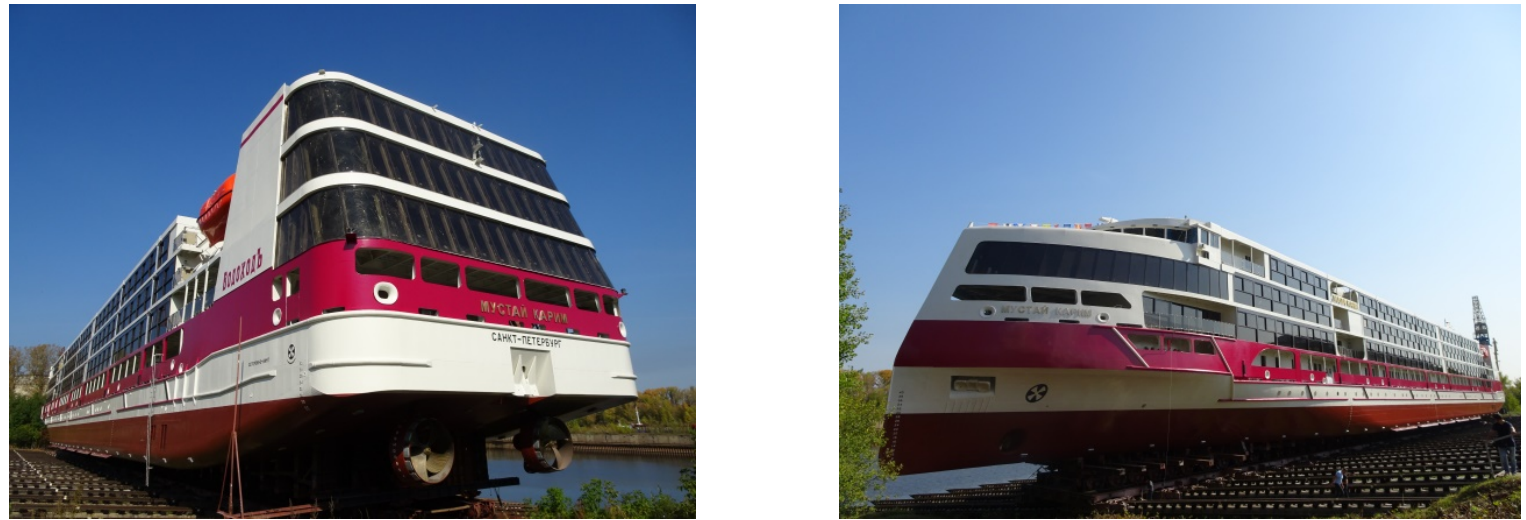

Рис. 8. Носовая и кормовая оконечности ПС проекта PV300 «Мустай Карим»
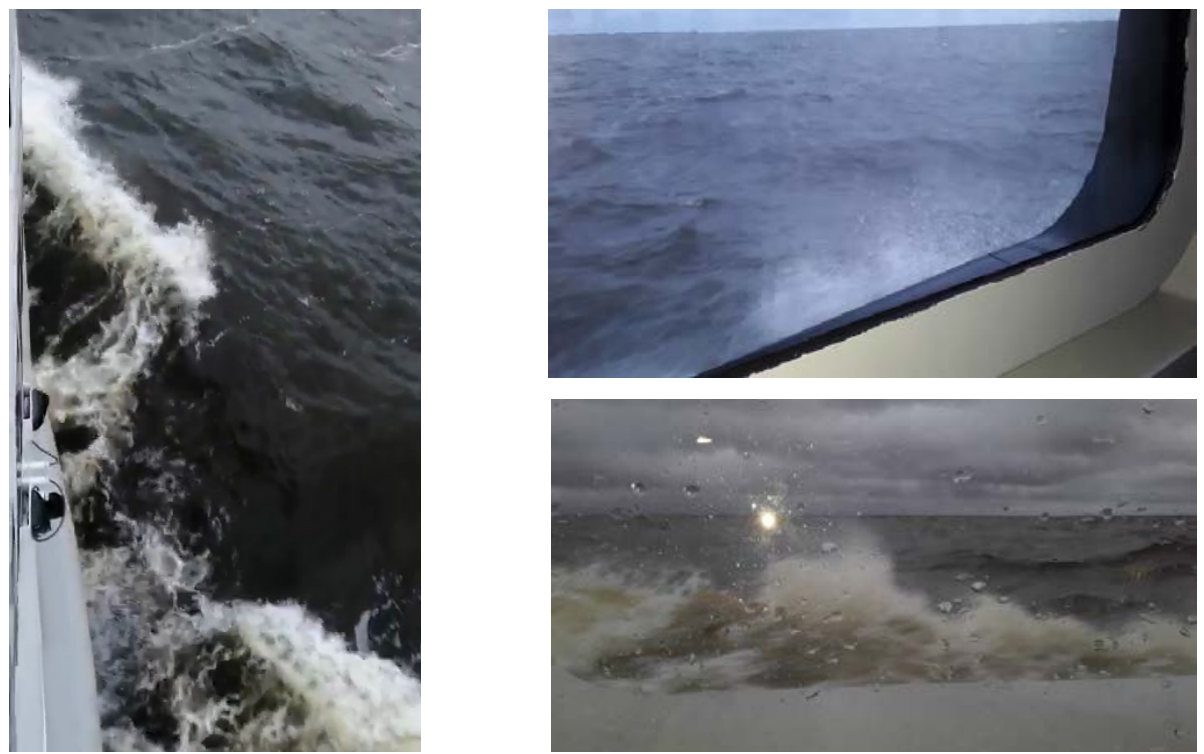

Рис. 9. Мореходные испытания ПС проекта PV09 (фактическая забрызгиваемость окон в носовой части судна на расчётной волне 


\section{СУДНОБУДУВАННЯ № 1 г 2020}

КУВ $0^{\circ}$ от 21,0 до 18,8 км/ч (фактическое волнение $h_{3 \%}=2,32$ м), нормальную обитаемость.

Нарушений в работе СЭУ, оголения днища, всхожести на волну и зарывания в волну не наблюдалось. Судно прорезало волну без видимых усилий или эффектов. Замечаний к кораблестроительным элементам судна не было.

Проведённые в 2019 году натурные мореходные испытания в условиях расчётного ветро-волнового режима подтвердили, что мореходные качества ПС проекта PV09 «Штандарт» соответствуют спецификационным требованиям. Мореходные качества судна соответствуют классу РРР М-ПР 2,5, который присвоен судну.

\section{ОБСУЖДЕНИЕ ПОЛУЧЕННЫХ РЕЗУЛЬТАТОВ И ВЫВОДЫ}

Выполнено исследование ходовых качеств ПС нового поколения. Эти суда отличаются от классических проектов ПС, построенных в советское время, соотношением $\mathrm{L} / B$ - в большинстве своём («Днепро макс»/《Волго-Дон макс» и «ПостДнепро макс»/«Волго-Балт макс» классы) более длинные, обводами носовой и кормовой оконечностей - оптимизированы с помощью методов ВГД, а также спроектированы с учётом установки подруливающих устройств и ВРК соответственно.

Удовлетворительная сходимость результатов модельных и натурных мореходных испытаний на примере ПС проекта PV09 показывает эффективность применяемых инструментов.

\section{REFERENCES}

[1] Egorov, G. V., Egorov, A. G., Ilnytskyi, I. A. (2019). Design features of river-sea cruise passenger vessels for Russian inland waterways and adjacent seas. Papers of the Intern. Conf. "Design \& Operation of Passenger Ships". London (UK): Royal Institution of Naval Architects, pp. 21-29.

[2] Egorov, A. G., Egorov, G. V. (2020). River and river-sea cruise passenger ships. Operational experience, prognosis and novel concepts. Proceedings of the Intern. Conf. "Sustainable and Safe Passenger Ships". Athens (Greece): Royal Institution of Naval Architects \& Hellenic Institute of Marine Technology, pp. 133-143.

[3] Egorov, G. V., Ilnytksiy, I. A., Kalugin, Ya. V. (2013). "Lineyka” kruiznykh passazhirskikh sudov dlya vnutrennikh vodnykh putey ["Lineup" of cruise passenger ships for inland waterways]. Odessa: Vestnik ONMU, No. 2 (38), pp. 20-40 [in Russian].

[4] Lyubimov, V. I. (2018). Osobennosti arkhitekturno-konstruktivnogo tipa sovremennykh rechnykh kruiznykh sudov [Features of architectural-construction type of modern river cruise ships]. Nizhniy Novgorod: Vestnik VGAVT, No. 55, pp. 49-55 [in Russian].

[5] Semin, A. A. (2013). Klassifikatsiya sposobov otsenki komfortabel'nosti kak sostavlyayushchiy element proyektirovaniya sudov i organizatsii obsluzhivaniya passazhirov [Classification of assessment methods of comfort levels as basic element of design ships and organization of passenger service]. Odessa: Vestnik ONMU, No. 1 (37), pp. 180-187 [in Russian].

[6] Zverkhovskyi, O., De Jong, J. S. (2020). DAMEN air cavity system of sustainable passenger ships. Proceedings of the Intern. Conf. "Sustainable and Safe Passenger Ships". Athens (Greece): Royal Institution of Naval Architects \& Hellenic Institute of Marine Technology, pp. 65-70.

[7] Kolesnik, D. V. (2010). Sravneniye obshchey effektivnosti ispol'zovaniya VRK i traditsionnogo propul'sivnogo kompleksa na sudakh smeshannogo reka-more plavaniya [Comparison of overall efficiency of FPRP usage and traditional propulsion system on river-sea vessels] / Collection book of Int. sc.-pract. conf. in honor of 80 years anniversary of Prof. V. V. Kozlyakov. Odessa: Sudostroenie i sudoremont, pp. 131-136 [in Russian].

[8] VETH rudder propellers (2019). VETH propulsion by TwinDisc. Papendrecht, The Netherlands, $48 \mathrm{p}$.

[9] SCHOTTEL propulsion for next-generation Yangtze cruise vessel. (2020). "Schottel" website. Retrieved from: https://www. schottel.de/news-events/news/news-detail/?no_cache=1\&tx_ttnews\%5Btt_news \%5D=645 (Last accessed: 01.04.2020).

[10] Sasaki, N., Kuribayashi, S., Fukazawa, M., Atlar, M. (2020). Towards a realistic estimation of the powering performance of a ship with a Gate Rudder System. Journal of Marine Science and Engineering, Volume 8, 1, paper 43.

[11] Bychkov, V. Ya., Grosheva, L. S., Plushaev, V. I. (2018). Matematicheskaya model' sudna s kolesnym dvizhitel'no-rulevym kompleksom "Zolotoye kol'tso" [Mathematical model of ship with steering-wheeled complex "Zolotoe Kolt'so"]. Astrakhan: Vestnik AGTU, No. 3, pp. 36-49 [in Russian].

[12] Egorov, G. V., Ilnytksiy, I. A., Stankov, B. N., Pechenyuk, A. A. (2011). Prorabotka variantov propul'sivnogo kompleksa sudna smeshannogo plavaniya klassa "Volgo-Don maks" [Workout of variants of propulsive complexes of river-sea vessel of Volgo-Don Max class]. Morskoy Vestnik, No. 2 (38), pp. 101-106 [in Russian].

[13] (2011). Issledovaniye khodovykh kachestv passazhirskogo sudna na 300 passazhirov [Study of running characteristics of passenger ship for 300 passengers]. Technical report DMT-11-084. 39 p. [in Russian].

[14] (2011). Issledovaniye khodovykh kachestv passazhirskogo sudna na 150 passazhirov [Study of running characteristics of passenger ship for 150 passengers]. Technical report DMT-11-086. 38 p. [in Russian].

[15] (2011). Issledovaniye khodovykh kachestv passazhirskogo barzhe-buksirnogo sostava na 250 passazhirov [Study of running characteristics of passenger tug-barge combination for 250 passengers]. Technical report DMT-11-088. 39 p [in Russian].

[16] (2012). Issledovaniye khodovykh kachestv passazhirskogo sudna [Study of running characteristics of passenger ship]. Technical report DMT-12-095. 35 p. [in Russian].

[17] (2014). Trial performance prediction with open FP propellers: trial prediction of project PV09 // Rolls-Royce, 2 p.

[18] (2019). Programma naturnykh morekhodnykh ispytaniy v usloviyakh raschetnogo vetro-volnovogo rezhima [Program of full-scale seaworthy trials at calculated wind-wave regime]. Volume MIB.5372, 18 p. [in Russian]. 
[19] (2019). Protokol naturnykh morekhodnykh ispytaniy v usloviyakh raschetnogo vetro-volnovogo rezhima [Log sheet of fullscale seaworthy trials at calculated wind-wave regime]. Volume MIB.5420, 38 p. [in Russian].

\section{СПИСОК ИСПОЛЬЗОВАННОЙ ЛИТЕРАТУРЫ}

[1] Egorov, G. V., Egorov, A. G., Ilnytskyi, I. A. (2019). Design features of river-sea cruise passenger vessels for Russian inland waterways and adjacent seas. Papers of the Intern. Conf. "Design \& Operation of Passenger Ships". London (UK) : Royal Institution of Naval Architects. Pp. 21-29.

[2] Egorov, A. G., Egorov, G. V. (2020). River and river-sea cruise passenger ships. Operational experience, prognosis and novel concepts. Proceedings of the Intern. Conf. "Sustainable and Safe Passenger Ships". Athens (Greece) : Royal Institution of Naval Architects \& Hellenic Institute of Marine Technology. Pp. 133-143.

[3] Егоров, Г. В., Ильницкий, И. А., Калугин, Я. В. (2013). «Линейка» круизных пассажирских судов для внутренних водных путей. Вісник ОНМУ. Одеса : ОНМУ. Вип. 2 (38). С. 20-40.

[4] Любимов, В. И. (2018). Особенности архитектурно-конструктивного типа современных речных круизных судов. Вестник ВГАВТ. Раздел I: Судостроение, судоремонт и экологическая безопасность судна. Вып. 55. Нижний Новгород : ВГАВТ. С. 49-55.

[5] Семин, А. А. (2013). Классификация способов оценки комфортабельности как составляющий элемент проектирования судов и организации обслуживания пассажиров. Вестник ОНМУ. Одесса : ОНМУ. Вып. 1 (37). С. $180-187$.

[6] Zverkhovskyi, O., De Jong, J. S. (2020). DAMEN air cavity system of sustainable passenger ships. Proceedings of the Intern. Conf. "Sustainable and Safe Passenger Ships". Athens (Greece) : Royal Institution of Naval Architects \& Hellenic Institute of Marine Technology. Pp. 65-70.

[7] Колесник, Д. В. (2010). Сравнение общей эффективности использования ВРК и традиционного пропульсивного комплекса на судах смешанного река-море плавания. Сборник докладов междун. научно-практ. конф. в честь 80-летнего юбилея профессора В.В. Козлякова. Одесса : Судостроение и судоремонт. 2010. С. 131-136.

[8] VETH rudder propellers. (2019). VETH propulsion by TwinDisc. Papendrecht, The Netherlands. 48 p.

[9] SCHOTTEL propulsion for next-generation Yangtze cruise vessel. (2020). Сайт компании «Schottel». URL: https://www. schottel.de/news-events/news/news-detail/?no_cache=1\& tx_ttnews\%5Btt_news\%5D=645 (дата обращения: 01.04.2020).

[10] Sasaki, N., Kuribayashi, S., Fukazawa, M., Atlar, M. Towards a realistic estimation of the powering performance of a ship with a Gate Rudder System. Journal of Marine Science and Engineering, 2020. Volume 8, 1, paper 43.

[11] Бычков, В. Я., Грошева, Л. С., Плющаев, В. И. (2018). Математическая модель судна с колёсным движительно-рулевым комплексом «Золотое кольцо». Вестник АГТУ. Серия: Морская техника и технология. № 3. Астрахань : АГТУ. C. 36-49.

[12] Егоров, Г. В., Ильницкий, И. А., Станков, Б. Н., Печенюк, А. А. (2011). Проработка вариантов пропульсивного комплекса судна смешанного плавания класса «Волго-Дон макс». Морской вестник. № 2 (38). С. 101-106.

[13] (2011). Исследование ходовых качеств пассажирского судна на 300 пассажиров: технический отчёт DMT-11-084. $39 \mathrm{c}$.

[14] (2011). Исследование ходовых качеств пассажирского судна на 150 пассажиров: технический отчёт DMT-11-086. $38 \mathrm{c}$.

[15] (2011). Исследование ходовых качеств пассажирского барже-буксирного состава на 250 пассажиров: технический отчёт DMT-11-088. 39 с.

[16] (2012). Исследование ходовых качеств пассажирского судна: технический отчёт DMT-12-095. 35 с.

[17] (2014). Trial performance prediction with open FP propellers: trial prediction of project PV09. Rolls-Royce. 2 p.

[18] (2019). Программа натурных мореходных испытаний в условиях расчётного ветро-волнового режима: Выпуск МИБ.5372. 18 с.

[19] (2019). Протокол натурных мореходных испытаний в условиях расчётного ветро-волнового режима: Выпуск МИБ. $5420.38 \mathrm{c.}$ 